\title{
Some Thoughts on Hot Money Problem
}

\author{
Wang Ting ${ }^{1}$ \\ Qiao $\mathbf{L i}^{1}$ \\ ${ }^{1}$ School of Economic and Management Administration, \\ North China Electric Power University, \\ Baoding, China \\ Yao Long ${ }^{1}$ \\ ${ }^{1}$ School of Economic and Management Administration, \\ North China Electric Power University, \\ Baoding, China \\ ${ }^{1}$ School of Economic and Management Administration, \\ North China Electric Power University, \\ Baoding, China
}

\begin{abstract}
Since 1990s, hot money has flooded into emerging countries and causes more frequent financial crisis in these countries. What's worse, as economic globalization and financial unification deepens, hot money scales up and is hard to discover. This paper studies hot money inflow channel, hot money's effect on China and some actual situation about hot money. This research has important theoretical significance.
\end{abstract}

Keywords: hot money, refugee capital, speculative shortterm

\section{Introduction}

Hot money is called refugee capital or speculative shortterm capital. It means that in order to pursue the highest reward, the short-term speculative capital flows rapidly in the international financial market. The net inflow of hot money refers to the net inflow of international capital.

Since the 1980s, with the wave off of global economic integration, the general recognition of the market economy, academics, politicians and the business community across the world have endorsed the financial liberalization based on market efficiency and market fair. Financial innovation, derivatives and the rapid growth of the virtual economy, making the flow of cross-border funds become more frequent. But at the same time, Frequent movement of huge international hot money have pose a seriously affected on developing country, and thus reinforce the importance of the supervision of the international short-term hot money.

Since July 21 2005, the Chinese government restart the reform of RMB exchange rate formation mechanism, the RMB appreciation has been a hot topic in the international economy, after that a large number of international hot money flow into China.

\section{Hot Money Inflow Channel}

China is the world's fastest growing country in emerging market countries. Due to the presupposition of RMB appreciation, a large number of international hot money is attracted. However, because of China's strict foreign exchange controls, the inflow way of hot money has great concealment, which requires financial regulators particularly attention. According to the relevant research reports, Hot money flowing into China is mainly in the following ways: firstly, the false trade credit. In this channel, in order to overseas capital into China, domestic enterprises and foreign investors can be joined by artificially high price, advance payment, forged supply contract etc. Secondly, Equity capital increase in foreign investment. On the basis of original registered capital, foreign invested enterprises increase capital, according to expand the scale of production", "increase investment projects" and other reasons. Thirdly, income transfer. Through the different areas of remittance currency conversion trans regional operation, so that a lot of hot money are free. Fourthly, underground. The underground is the most efficient way to import foreign capital. If you take the money to a designated account of local when you are in Hong Kong or overseas, After confirmed, the interior underground banks will naturally open account and put your foreign currency into RMB. In addition, the container truck entrained cash and alimony are hot money circulation channels.

\section{Hot Money's Effect on China}

Hot money has a huge impact on the domestic people's livelihood. Firstly, the inflow of hot money leads to the improvement and the amount of money of domestic market. At the same time, the hot money which stays in the country, the prices will rise accordingly and domestic inflation will increase through speculation in commodities. Hot money flows to the real estate market will improve estate prices of China. It is a negative force OIN terms of the government regulation of prices. Therefore, it's bad for people's livelihood. 


\section{Some Actual Situation}

In terms of foreign capital which aims at earning RMB appreciation and rising prices and other premium income, Chinese real estate market undoubtedly has considerable appeal. Authoritative department officials have said that the way of foreign investment flowing into China's real estate market is quite concealment. But through the anatomy of some typical cases, there are indeed illegal credit funds into the real estate field. This year, in order to be suppressed prices completely, the market "combined" has been introduced by government. The purchase of the policy has been signs of open prices down channel. In such expected, the full amount of hot money to buy a house may be cash capital fled. But at the same time, the real estate regulation makes developers and abnormal tension. It will lead that private financing rates will soar. Therefore, we must be wary of the speech through the manufacturing of public opinion that China real estate leads to the collapse because of the price down. At the same time to refute publicity those who advocate the overseas investment speculators ready to buy the dips.

Hot money speculate by characteristics that some agricultural and sideline products is seasonal, regional and yield significantly small and then push up prices, which also needs timely intervention by the financial sector. According to reports, Zhou wangjun, deputy director of the national development and Reform Commission said that several measures can be taken to prevent hot money speculation phenomenon: First, do not allow speculation people the basic necessities of life, such as grain and eggs etc. Second, the government should further improve the system. Thirdly, establish a special mechanism. It means the trend of hot money should be monitored it strictly stop entering the real economy.

\section{Conclusion}

Since 1990s, hot money has flooded into emerging countries and causes much more frequent financial crisis in these countries. What's worse, as economic globalization and financial unification deepens, the hot money scales up and is hard to discover. This paper studies hot money inflow channel, hot money's effect on China and some actual situation about hot money. It has important theoretical significance.

\section{References}

[1] Graciela L. Kaminsky, Carmen M. Reinhar,1998:

"Financial Crises in Asia and Latin America: Then and Now", The American Economic Review, Vol.88,pp.444-448.

[2] Guillermo A. Calvo,1998: "Capital flows and capitalmarket crises: the simple economics of sudden stops", Journal of Applied Economics, Vol. 1,No. 1, pp. 35-54.
[3] Lucio Sarno, Mark P. Taylor,1999: "Hot money, accounting labels and the permanence of capital flows to developing countries : an empirical investigation", Journal of Development Economics, Vol. 59 , pp 337 364.

[4] HaliEdison, Carmen M. Reinhart, 2001 : "Stopping hot money,', Journal of Development Economics, Vol. 66,pp 533-553.

[5] Glick, Reuven, and Michael Hutchison. Capital controls and exchange rate instability in developing economies, Journal of International Money and Finance,2005,24:387-412.

[6] Roberto Cardarelli, Selim Elekdag and M.Ayhan Kose. Capital Inflows: Microeconomic Implications and Policy Responses, IMF Working Paper, 2009, 3:46-56.

[7] Andrew K. Rose. A stable international monetary system emerges: Inflation targeting is Bretton Woods reversed, Journal of International Money and Finance, 2007,26:15-18.

[8] Mende and Menkhoff,Tobin in tax Effects Seen from the Foreign Exehange Market's Mierostructure, Intemational finanee, Summer 2003, Vol 6 Issue2.

[9] Lyoha M.A:The Demand for Intemational Reserves in less Developed Countries,A Distribution Lag Speeifieation[J],Review of Eeonomics and Statisties, 1976.

[10] Klaus Friedrich,Charles D.Cathcart Short-term capital flows under flexible exchange rates[J]. Weltwirtschaftliches Archiv, 1977, Page: 48-57.

[11] Roberto Chang, Andres Velasco. Financial crises in emerging markets: a canonical model" [J].Federal Reserve Bank of Atlanta Working paper, 1998, Page:98-100.

[12] Robert Z, Aliber.Capital flows. Exchange Rates, and the New International Financial Architecture: Six Financial Crises in Search of a Generic [J]. Explanation Open Economies Review August 2000, Volume 11, Page: 43-61.

[13] Frank S. T. Hsiao, Mei-Chu W. Hsiao. Capital flows and exchange rates: recent Korean and Taiwanese experience and challenges [J].Journal of Asian Economics,2001, Page: 353-381.

[14] Carlos A.Ibarra. Capital Flows and Real Exchange Rate Appreciation in Mexico[J].World Development December 2011, Page:2080-2090.

[15] Juthathip Jongwanich, Archanun Kohpaiboon. Capital flows and real exchange rates in emerging Asian countries [J].Journal of Asian Economics, 2013, Page:138-146.

[16]Odongo Kodongo, Kalu OjahReal exchange rates, trade balance and capital flows in Africa[J].Journal of Economics and Business, March - April 2013,Page:22 -46 . 